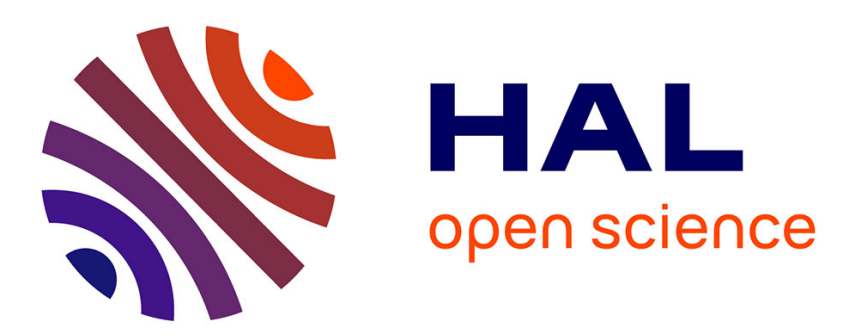

\title{
Note on the Cecidomyiidae from Guadeloupe (West Indies) with description of a new species of Paracalmonia (Diptera)
}

Raymond J. Gagné

\section{- To cite this version:}

Raymond J. Gagné. Note on the Cecidomyiidae from Guadeloupe (West Indies) with description of a new species of Paracalmonia (Diptera). Bulletin de la Société Entomologique de France, 2009, 114 (3), pp.337-350. hal-02664043

\section{HAL Id: hal-02664043 \\ https://hal.inrae.fr/hal-02664043}

Submitted on 31 May 2020

HAL is a multi-disciplinary open access archive for the deposit and dissemination of scientific research documents, whether they are published or not. The documents may come from teaching and research institutions in France or abroad, or from public or private research centers.
L'archive ouverte pluridisciplinaire HAL, est destinée au dépôt et à la diffusion de documents scientifiques de niveau recherche, publiés ou non, émanant des établissements d'enseignement et de recherche français ou étrangers, des laboratoires publics ou privés. 


\title{
Note on the Cecidomyiidae from Guadeloupe (West Indies) with description of a new species of Paracalmonia (Diptera)
}

\author{
by Raymond J. GAGNÉ* and Jean ÉTIENNE**
}

\begin{abstract}
*Systematic Entomology Laboratory, PSI, Agricultural Research Service, U.S. Department of Agriculture, c/o Smithsonian Institution MRC-168, P.O. Box 37012, Washington, D.C. 20013-7012, USA <raymond.gagne@ars.usda.gov> **Institut national de la Recherche Agronomique, Centre Antilles-Guyane, Domaine Duclos, F - 97170 Petit-

Bourg, Guadeloupe, French West Indies<jean.etienne@wanadoo.fr>
\end{abstract}

Summary. - Paracalmonia Özdikmen, a genus restricted to Ficus (Moraceae), is rediagnosed and a new species, Paracalmonia paucula Gagné \& Étienne, is described from leaf galls of Ficus citrifolia Mill. from Guadeloupe. Chrybaneura harrisoni Gagné, previously found associated with empty spider eggs from Central America is reported here from scale insect remains and other insect detritus and its larva and pupa are described for the first time. Lestodiplosis peruviana Felt, a predator of scale insects, is reported for the first time since it was described from Peru in 1911. The male is redescribed and the newly discovered female and larva are described. Pectinodiplosis erratica (Felt) is also reported for the first time since its description from a single male from Washington DC, USA, in 1908. The male is redescribed and the newly associated female is characterized. This species is a predator of Coccoidea and other insects.

Résumé. - Note sur les Cecidomyiidae de Guadeloupe (Antilles) et description d'une nouvelle espèce de Paracalmonia (Diptera). Paracalmonia Özdikmen, un genre inféodé aux Ficus (Moraceae), est défini à nouveau et une nouvelle espèce, $P$. paucula Gagné \& Étienne, qui produit des galles sur les feuilles de Ficus citrifolia Mill. en Guadeloupe est décrite. Chrybaneura harrisoni Gagné, trouvé en Amérique Centrale associé à des œufs vides d'araignées a été obtenu ici à partir de débris de Coccoidea et d'autres insectes. La larve et la pupe sont décrites pour la première fois. Lestodiplosis peruviana Felt, qui est un prédateur de cochenilles, est signalé pour la première fois depuis sa découverte au Pérou en 1911. Le mâle est décrit à nouveau, la femelle et la larve sont décrites pour la première fois. Pectinodiplosis erratica (Felt) est aussi signalé pour la première fois depuis sa description originale en 1908, sur un unique mâle provenant de Washington DC, USA. Le mâle est décrit à nouveau et la femelle décrite pour la première fois. Cette espèce est prédatrice de Coccoidea et d'insectes divers.

Keywords. - Diptera, Cecidomyiidae, Paracalmonia, Calmonia, Ficus, Coccoidea, predators, Western Hemisphere.

A long-term survey of galls and of cecidomyiid predators of Coccoidea in Guadeloupe by one of us (JE) has uncovered a great number of species new to Guadeloupe and to science. Reports on a few economically or otherwise important species from these discoveries have already been published in GAGNÉ \& ETIENNE (1996, 2006) and GAGNÉ et al. (2000). We report here on a species new to science, several remarkable rediscoveries, and some significant new findings concerning the biology and morphology of Cecidomyiidae.

Paracalmonia Özdikmen, 2009, was previously known from two partially characterized Brazilian species forming leaf galls on Ficus spp. (Moraceae). The original generic description, as Calmonia Tavares, 1917, was based on suboptimal material, so the genus is rediagnosed here. A new species is described from Ficus citrifolia Mill. (Moraceae) and separated from the other two species. The male, female, and larva have very unusual character states for the supertribe Oligotrophidi: the mediobasal gonocoxite lobe of the male genitalia is uniquely distant from the aedeagus, the female has separate cerci that are foreshortened and blunt posteriorly, and the larva has lost most of the normal complement of papillae seen elsewhere in Cecidomyiidae.

Chrybaneura harrisoni Gagné, 1968, described from adults of both sexes bred in associa- 
tion with empty spider eggs and egg cases in Panama and Costa Rica, is now reported from spent coccoid colonies in Guadeloupe, as well as from other coccoids in USA and a lepidopteran in Bolivia. The larva and pupa are described for the first time and larval Brachineuridi are reviewed.

Two predaceous cecidomyiids were recently discovered in association with scale insects in Guadeloupe, far from where they were initially found. Lestodiplosis peruviana Felt, 1911, was originally described from a male and a series of larvae from Peru, preying on Pinnaspis strachani (Cooley) (as Hemichionaspis minor Maskell) (Hemiptera: Coccidae). The unique male was mounted uncleared in balsam with the genitalia in side view so that it was not possible to characterize or identify without additional specimens (HARRIS, 1968). Larvae, also described in FELT (1911), from a separate but nearby locality from the male, and ostensibly preying on the same host, belong instead to Arthrocnodax meridionalis Felt (GAGNÉ, ms in preparation), a species known from elsewhere in the Neotropics as a predator of eriophyid mites (Acarina). The male is redescribed and the female and larva of L. peruviana are described for the first time. The other species is the monotypic Pectinodiplosis erratica Felt, 1908, initially described from a single male with a code number the only associated data. Many years later the code number was located in US Department of Agriculture card files giving the collection host and locality as Hemerocampa leucostigma J. E. Smith (Lepidoptera: Lymantriidae) from Washington, DC, USA (GAGNÉ, 1973). The series from Guadeloupe is the only other discovery of this species, and the female is described for the first time. The present discovery of this species on coccoids indicates that it is a general predator.

\section{METHODS AND MATERIALS}

The collections from Guadeloupe are part of a long-term study by one of us (JE) to survey several groups of insects on that island. Larvae of predators associated with coccoids and of phytophagous cecidomyiids were, after samples of larvae were preserved in alcohol, separately caged to obtain adults. Adult and pupal samples were also saved in alcohol. Specimens were later mounted on microscope slides using the method outlined in GAGNÉ (1989). Terminology for adult morphology follows usage in MCALPINE et al. (1981) and for larval morphology that in GAGNÉ (1989). The abbreviation USNM is used for the National Museum of Natural History, Washington, DC, USA.

\section{Paracalmonia Özdikmen, 2009}

Calmonia Tavares, 1917: 173, preoccupied by Calmonia Clarke, 1913: 119 (Trilobita).

Paracalmonia Özdikmen, 2009: 201, new name for Calmonia Tavares.

Diagnosis. - Adult: Antenna with 8-10 flagellomeres in both sexes, those of male (except last) with long necks, those of females without. Palpus 1-segmented. Scutum with 4 rows of setae mixed with few scales. Scutellum with group of setae on each side. Wing (fig. 13): $C$ and $\mathrm{R}_{5}$ joined at about 3/4 wing length; $\mathrm{C}$ broken beyond juncture with $\mathrm{R}_{5}$; $\mathrm{M}$ not apparent; $\mathrm{Cu}$ forked. Acropod (fig. 11-12): claws with large basal tooth; empodia about as long as claws; pulvilli about 1/3 length of claws. Abdominal tergites and sternites without anterior pair of trichoid sensilla, tergites with no more than single posterior row of setae, 0 lateral setae, and mostly covered elsewhere with scales. Male genitalia (fig. 6, 15-16): hypoproct concave apically; aedeagus cylindrical, horizontally divided at bulbous apex; mediobasal lobe of gonocoxite short, rounded, not covering side of aedeagus; gonostylus widest at base, narrowed beyond, completely setulose. Female posterior tergites subequal in length, undivided; ovipositor (fig. 3-5) shortprotrusible, cerci separate, foreshortened, the posterior surface blunt, thickly setose with several peglike sensilla. Last instar larva (fig. 17-18): Spatula present. At least P. paucula, n. sp., with metathoracic spiracles in addition to those on prothorax and first 8 abdominal segments, and showing great reduction in number of regular papillae found on most other Cecidomyiinae. 

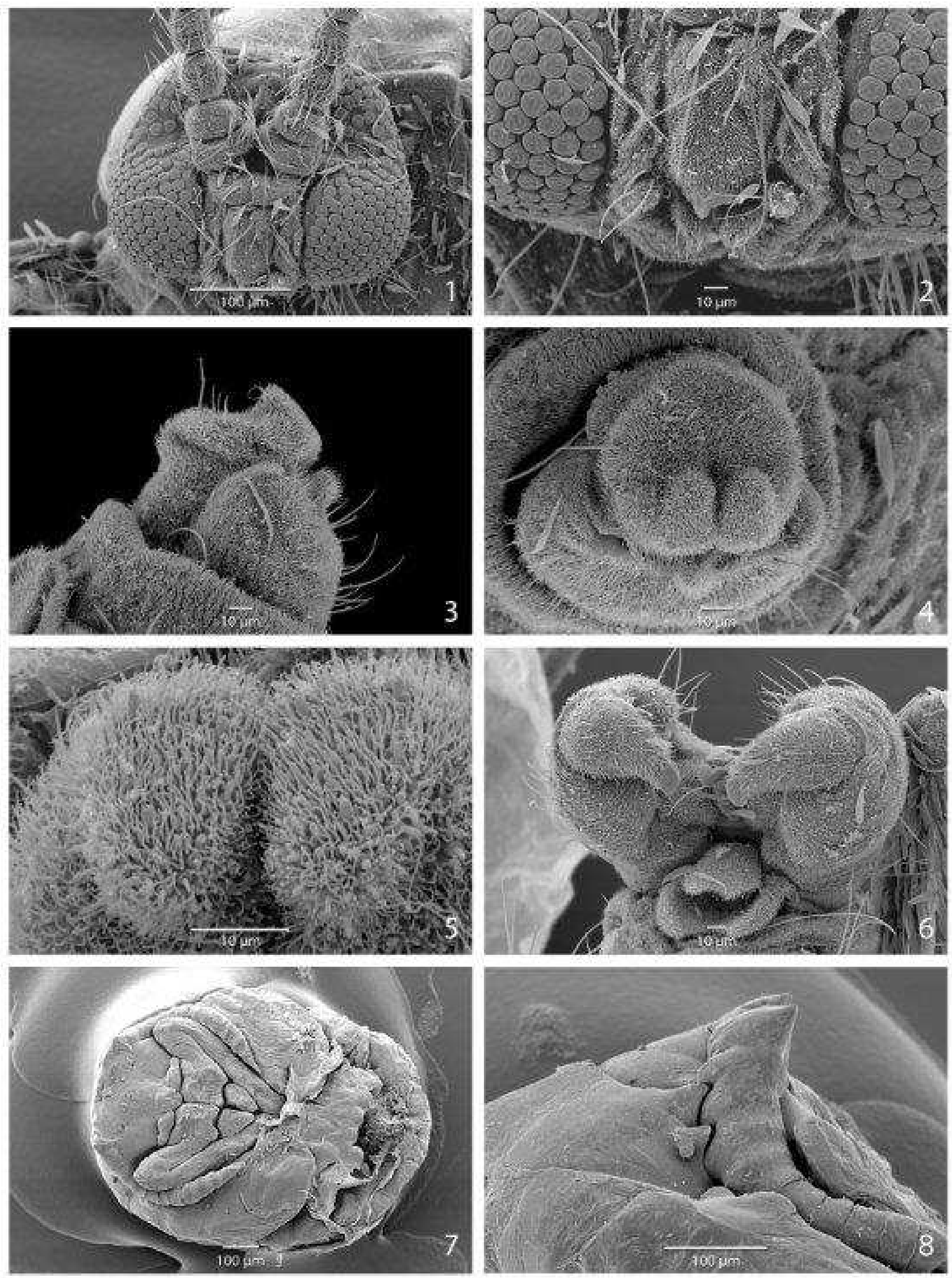

Fig. 1-8. - Paracalmonia paucula. - 1, Female head (anterior). - 2, Same, detail of lower head. - 3, Female postabdomen (lateral). - 4, Same (posterior). - 5, Female cerci (posterior). - 6, Male genitalia (posterior). 7, Pupa (ventral). -8 , Head of pupa, (lateral).

Remarks. - Paracalmonia belongs to the supertribe Lasiopteridi on the basis of the particular makeup of the male antennae. The genus was keyed for convenience in the tribe Oligotrophini in GAGNÉ (1994), but it does not convincingly fit into any of the available tribes currently used for the supertribe. The particular distinctions of this genus are as follows: the 
palpus is one-segmented; the mediobasal gonocoxite lobe is separate from instead of clasping the aedeagus as in other Lasiopteridi; the female cerci are not fused together and are foreshortened and apically blunt; and the larva (known for only one of the three Paracalmonia spp.) has metathoracic spiracles, unique in Cecidomyiidae, and lacks most of the basic complement of papillae found elsewhere in the Lasiopteridi. Of the possible 200 regular thoracic and abdominal papillae found on most Lasiopteridi, Paracalmonia paucula bears only 24 .

The regular presence of metathoracic spiracles in $P$. paucula is unique in Cecidomyiidae and is evidently a reversal. MöHN (1955) reported that in the large number of larvae he studied for his work on Central European Cecidomyiidae he found the occasional specimen with metathoracic spiracles but it was never a regular specific character. All the larvae we have of $P$. paucula have metathoracic spiracles, but it remains to be seen whether the two other species of Paracalmonia also have them.

Paracalmonia was previously known from two species reared from Ficus spp. in Brazil (TAVARES, 1917). Paracalmonia urostigmatis (Tavares, 1917), an automatic new combination from Calmonia, was described from the larva (color only), pupa, and adults of both sexes taken from a blister gall on Ficus sp. collected in 1911 in Nova Friburgo, Rio de Janeiro, Brazil. The host was given as Urostigma sp. (=Ficus sp.), with the Portuguese common names figueira brava and figueira do inferno. A series of adults was sent to E.P. Felt in Albany, New York, USA, by Tavares, specimens used here to separate that species from $P$. paucula and diagnose the genus. The gall was described as a convex swelling 1.0 to $1.5 \mathrm{~mm}$ diameter on the upper side of the leaf and 1.0-2.0 mm diameter on the lower, but on the lower surface with a central cylindrical chimney extending about $1 \mathrm{~mm}$ beyond the convexity. Tavares gave no figure of the gall, but HOUARD (1933) provided an illustration based on specimens he received from Tavares. The second species of Paracalmonia, originally named Asteromyia urostigmatis Tavares, 1917, was described from a shed third instar larval skin (only the spatula was noted) and a pupa containing a female. This series was taken from a blister gall generally similar to that of P. urostigmatis on Ficus sp. (as Urostigma sp. with the Portuguese common name gamelleiras) collected iv.1912 and viii.1913, S. Antonio da Barra, Bahia, Brazil. This gall was also illustrated in HOUARD (1933) based on specimens received from Tavares. Tavares's descriptions of the two species do not appear very different, at least in adult characters, and were placed in the same genus in GAGNÉ (1994), in which the second species, a homonym, was renamed Calmonia fici Gagné and is now an automatic new combination in Paracalmonia. One possible reason Tavares placed the two species in different genera may have been that the pupal antennal bases of $P$. fici are large and three-pronged while those of $P$. urostigmatis are not produced. Differences in pupal antennal bases of gall midges appear to be adaptive and can differ greatly in even closely related species (e.g., see RUSSO, 2008). HOUARD (1933) attributed several other lamina galls on Ficus (and Urostigma) to unidentified cecidomyiids, which indicates that additional species of Calmonia may be found on that host in the Neotropics.

\section{Paracalmonia paucula n. sp. (fig. 1-18)}

Description adult. - Head (fig. 1-2): Eye facets circular, contiguous except those near midheight separated by about $1 / 2$ eye facet diameter; eyes separated at vertex by about twice eye facet diameter. Antenna with 10 flagellomeres in male, 8-10 in female, the last two in female usually connate; necks of first through ninth male flagellomeres (fig. 9) about as long as node; female flagellomeres (fig. 10) without necks. Frons with 6-7 setae and no scales. Labellum hemispherical in frontal view, with several short, thick, pointed setae. Palpus 1-segmented, with several elongate setae.

Thorax: Anepisternum with 2-5 setae dorsally; anepimeron with vertical row of 5-8 setae; pleura otherwise bare. Wing (fig. 13): length 1.3-1.4 $\mathrm{mm}$ in both sexes; $\mathrm{R}_{5}$ short, reaching $\mathrm{C}$ at about $3 / 4$ wing length, slightly bowed posteriorly. Acropod as in fig. 11-12. 

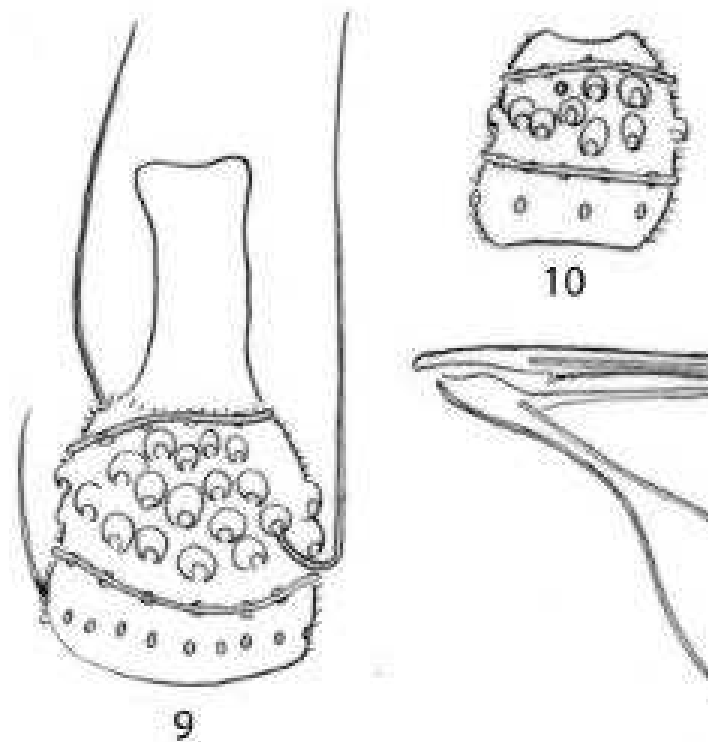

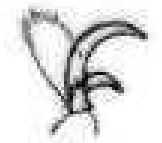

11

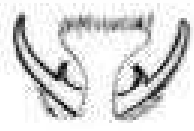

12
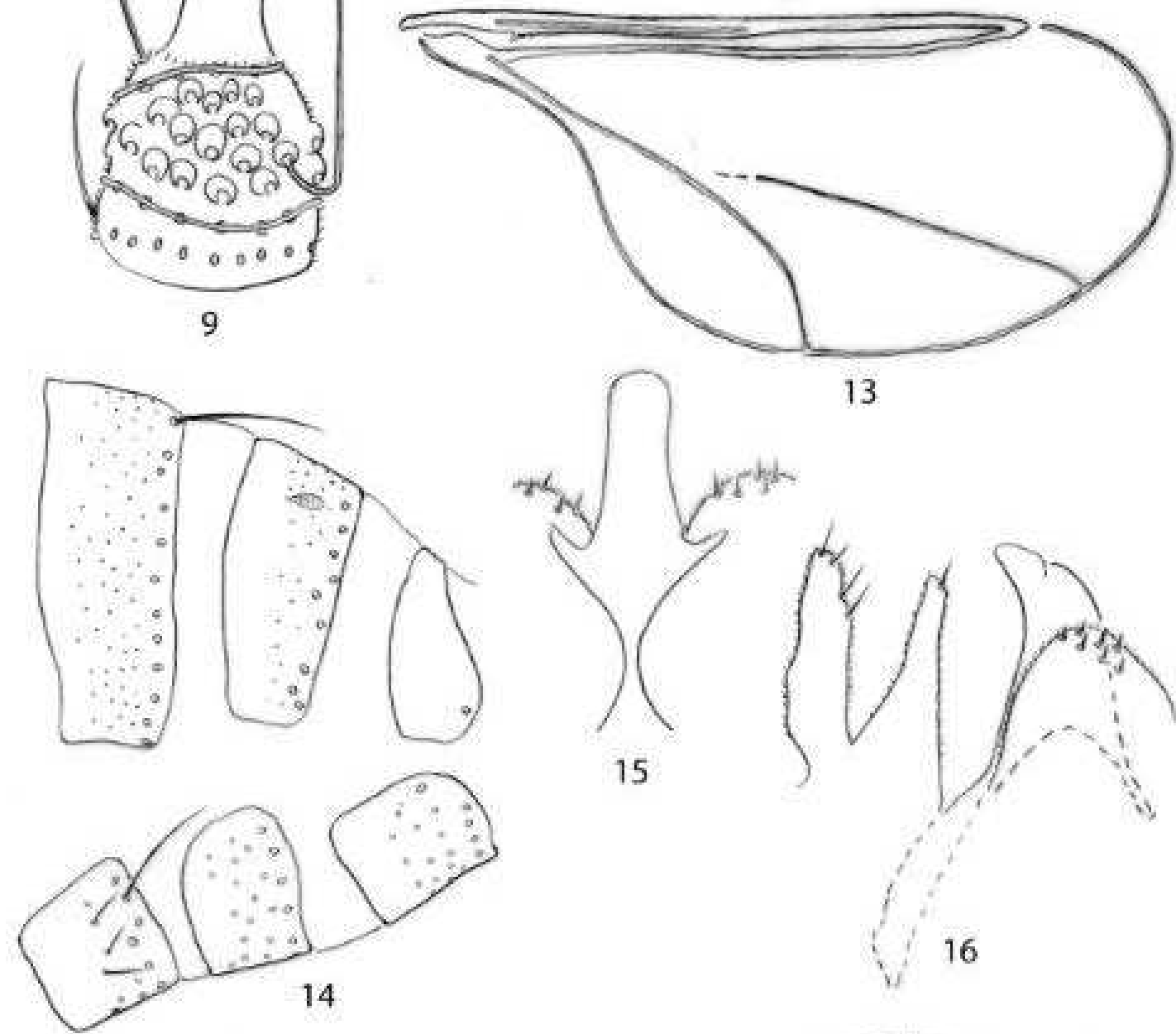

15

\section{3}

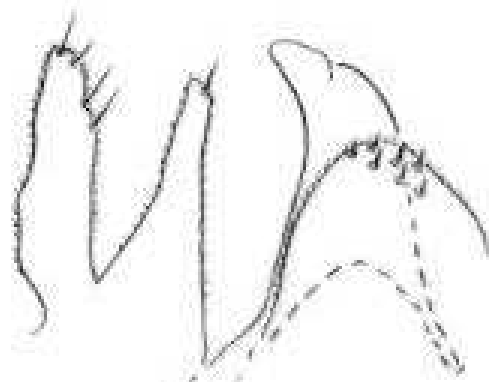

16

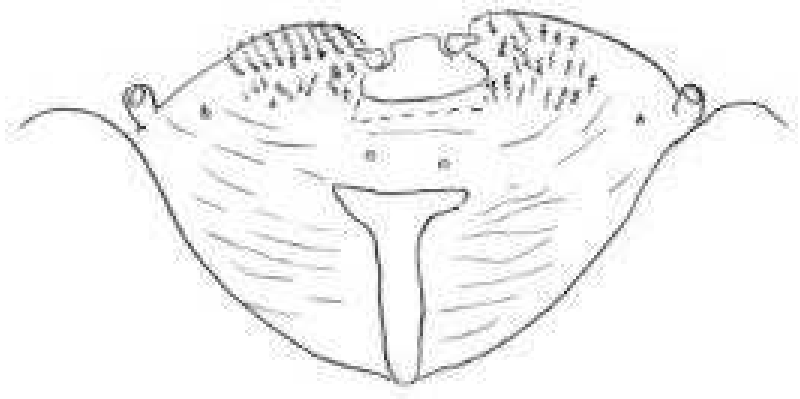

17

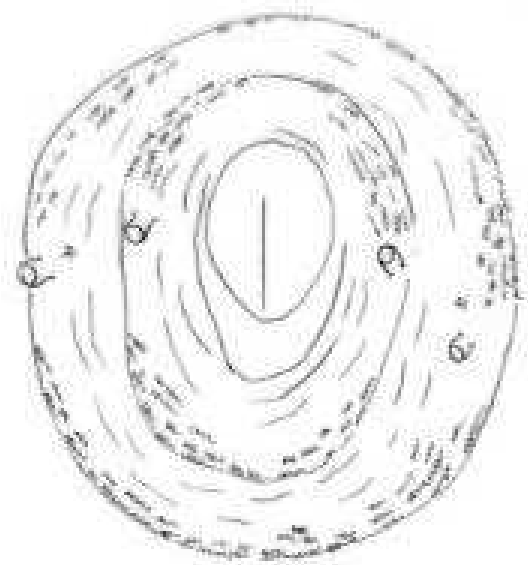

18

Fig. 9-18. - Paracalmonia paucula. - 9, 10, Third flagellomere (ventral) male and female. - 11-12, Acropod (lateral and dorsal). - 13, Wing. - 14, Male abdominal segments six through eight (lateral). - 15, Aedeagus and gonocoxal lobes (ventral). - 16, Cercus, hypoproct, aedeagus and gonocoxal lobes (lateral). - 17, Third instar larva, head collar segment and prothorax (ventral). - 18, Same, abdominal segments seven to last (posterior; artificially compressed).

Male abdomen (fig. 14): Terga and sterna without anterior pair of trichoid sensilla; first through seventh tergites wide, straplike; first through sixth with single row of long posterior setae, scattered scales covering terga; seventh tergite with irregular but mostly single row of posterior setae, scales present only on anterior half; eighth tergite with 0-2 setae on posterolateral corners and 0 scales; second through seventh sternites rectangular with posterior row of elongate setae and midlength row or rows of short setae; eighth 
sternite with posterior row of elongate setae and covered elsewhere with short setae. Genitalia (fig. 6, 15-16): cerci triangular, with lateral row of short setae ending at pointed apex; hypoproct concave posteriorly, a single seta present at apex of each resulting lobe; aedeagus cylindrical with horizontal crease apically, the distal dorsal section bulbous; gonocoxite short-cylindrical, mediobasal lobe short, rounded, not clasping aedeagus except basally; gonostylus short-bulbous, tapering abruptly before toothed apex, completely setulose.

Female abdomen: First through seventh tergites as in male, except seventh with scales covering all of tergite anterior to posterior setal row; eighth tergite without vestiture except for covering of microsetulae; second to seventh sternites as for male; eighth not differentiated. Ovipositor (fig. 2-4) protrusible but short, eighth segment about as long as seventh and as high as long; ninth segment with dorsoapical, horizontal row of setae and scattered ventral setae; cerci foreshortened, higher than long, blunt-tipped, the resulting flat posterior surface thickly covered with short, pointed setae and peglike sensoria; hypoproct bulbous.

Pupa (fig. 7-8). - Body dorsoventrally flattened, elliptical, length, 1.0.1.2 $\mathrm{mm}$. Head wider than long. Vertex weakly convex with anterolateral pair of papillae, one of each pair with short seta, the other without seta and situated on a conical prominence. Antennal bases short, slightly produced ventrally, tapering to acute angle, the vertical margin carinate; distance between antennal bases nearly as wide as face. Face smooth, without papillae. Labella and palpi short. Prothoracic spiracles diminutive, barely longer than wide. Abdominal tergites almost entirely covered with uniform, tiny spicules, the spiracles no longer than wide.

Third instar larva (fig. 17-18). - Body dorsoventrally flattened, elliptical, length, 1.0.1.3 mm. Head capsule hemispherical, without lateral apodemes; antennae diminutive, pear-shaped, directed laterally. Spiracles present on pro- and metathorax and on first through eighth abdominal segments. Integument with mesally directed field of spicules on each side of collar segment and anterior spicules on dorsum and venter of first through eighth abdominal segments; otherwise smooth, crossed with weak, mostly horizontal striae. Spatula wedge shaped, anterior margin widest, straight. Papillae mostly lost; remaining are: a pair of sternal papillae without setae on prothorax anterior to spatula (none on mesoand metathorax); on each of thoracic and abdominal segments one dorsal short-setose papilla on each side (presumably the lateralmost of the three usually found on other cecidomyiids) and one short-setose pleural papilla laterad of each spiracle, or in the case of the mesothorax, in line with the other pleural papillae, the dorsal papilla usually missing on sixth through eighth abdominal segments.

HolotyPE. - $\widehat{O}$, reared from Ficus citrifolia, Petit-Canal, Guadeloupe, 27.VII.2007, J. Étienne, GR 3720, deposited in USNM.

Other specimens examined (all from Ficus citrifolia in Guadeloupe and deposited in USNM and the Étienne collection in Lamentin, Guadeloupe). - 4 ऽ, 5 ㅇ , 4 pupae, 5 larvae, same data as holotype;

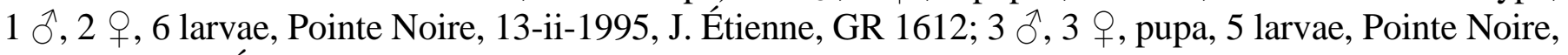
11-vii-1995, J. Étienne, GR 1669.

Etymology. - The name paucula is Latin meaning very few, with reference to the greatly reduced number of larval papillae.

Remarks. - This species differs most prominently from P. urostigmatis in the stout and foreshortened instead of long and more gradually tapering gonostylus, and the much shorter ovipositor, which is about as long as high instead of more than twice as long as high. Paracalmonia paucula has much shorter pupal antennal bases than does P. fici [cf. fig. 7, pl. XI of TAVARES (1917)].

Chrybaneura harrisoni Gagné, 1968 (fig. 19-24)

This species was originally described from males and females reared in Panama and Costa Rica from larvae associated with empty spider eggs and egg cases. One of us (JE) recently reared adults and obtained the previously unknown pupae and larvae of this species in Guadeloupe from among the remains of old, dead colonies of Icerya seychellarum (Westwood) (Hemiptera: Monophlebidae). The small supertribe Brachineuridi, to which Chrybaneura belongs, has only 80 known species (GAGNÉ, 2004, and additional species published since 2004). 
The biology of most of them remains unknown, but some species have been reared from insect remains, mushrooms, or other niches (GAGNÉ, 2004).

The description of the adult stage can be found in GAGNÉ (1968). Descriptions of the pupa and larva are as follows.

Pupa (fig. 23-24). - Length, 0.9-1.4 mm (n=5). Body elongate-cylindrical. Vertex with two pairs of papillae on each side, one of each pair without, the other with long seta. Antennal bases short, rounded. Face smooth, without ventral protrusions. Labrum triangular with 6 papillae, most with short seta no longer than basal diameter of papilla. Prothoracic spiracles long, thin, sigmoid. Abdominal spiracles evident on second through fifth segments, about three times as long as basal width. First abdominal tergum with a few rows of short spicules anteriorly, second through eighth terga with many rows of spicules at midlength, those at anterior center much larger than remainder. Terga each with 6 setose dorsal papillae situated among posteriormost rows of spicules.
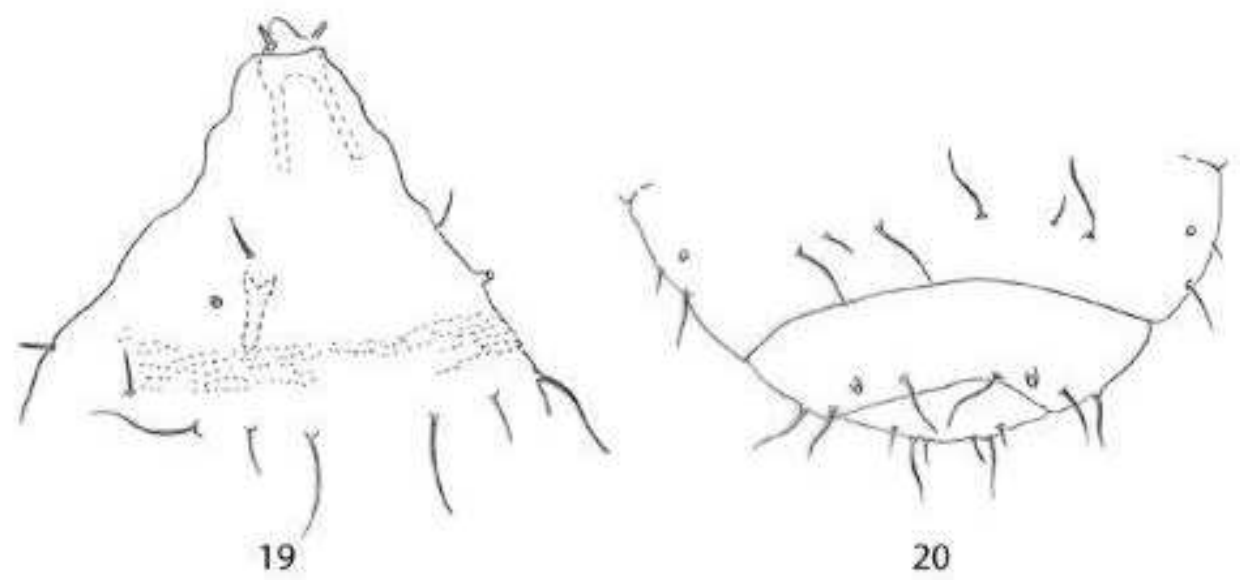

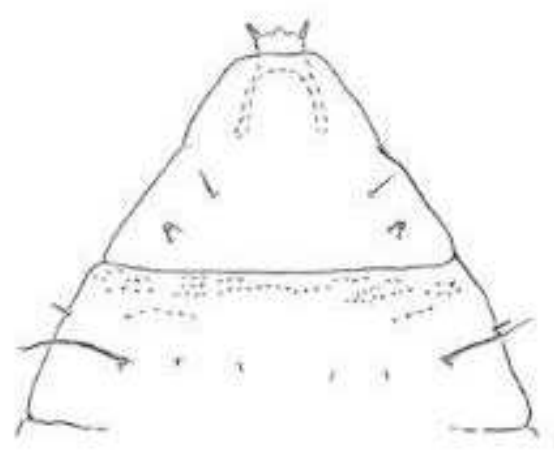

21

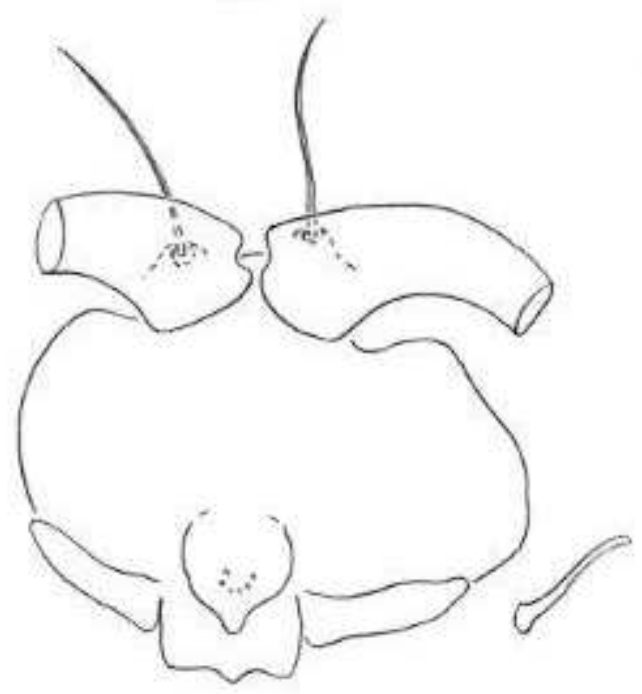

23

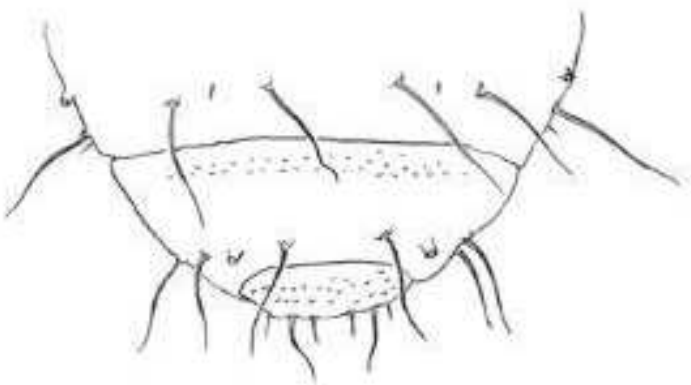

22

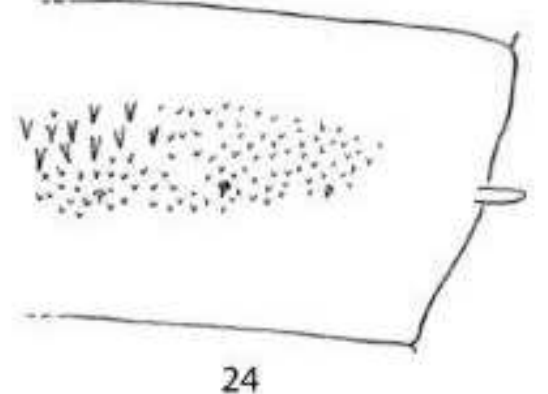

24

Fig. 19-24. - Chrybaneura harrisoni. - 19-20, Third instar larva: 19, head through mesothorax (dorsolateral); 20, seventh abdominal through terminal segment. - 21-22, Second instar larva (dorsal): 21, head through mesothorax; 22, seventh abdominal through terminal segment. - 23-24, Pupa: 23, parts of head and prothoracic spiracle (ventral); 24, right half of fifth abdominal segment (dorsal). 
Third instar larva (fig. 19-20). - Length, 1.0-1.6 mm (n=3). Body elongate-cylindrical, dorsoventrally flattened. Head capsule robust, conical, with elongate lateral apodemes; antennae about twice length of basal diameter. Spiracles present on prothorax and first through eighth abdominal segments, the prothoracic and last abdominal pairs larger than the remainder. Integument mostly smooth, several irregular rows of spicules present anterodorsally from mesothorax to fifth abdominal segment, diminishing in number from thorax to fifth abdominal segment, and present anteroventrally from mesothorax to terminal segment. Spatula clove-shaped. Papillae as follows: sternals asetose, 2 present on each thoracic segment, 4 each on first through eighth abdominal segments; 6 lateral papillae on each side of midline of thoracic segments, arranged as two triplets, 2 of each with diminutive setae, one asetose; dorsals all setose, 2 on prothorax, 6 on mesothorax through 7th abdominal segments, setae of inner and outer pairs appreciably longer than that of remaining pair, 2 on eighth abdominal segment with elongate setae; 1 pleural on each side of prothorax, 2 pleurals on each side of meso- and metathorax and first through eighth abdominal segments, the more dorsal pleural papilla with longer seta except both subequal on eighth abdominal segment; terminal segment with 6 papillae, two with elongate setae, the remaining papillae with much shorter setae.

Second instar larva (fig. 21-22). - Length, 0.7-1.2 mm ( $\mathrm{n}=5)$ As for third instar except spatula absent and meso- and metathoracic dorsal papillae with setae of only the outer pair very long, the setae of the two inner pairs diminutive.

Specimens examined. - 10 larvae, 4 pupae, with dead colony of Icerya seychellarum, Guadeloupe, Lamentin, Ravine-Chaude, 7.iv.2008, J. Étienne, GP 2621; 3 ô, 1 q, same data except 28.vii.2007, GP 2539. In addition to this material, the following series of $C$. harrisoni were newly discovered in the USNM collection: $4 \hat{\sigma}$, associated with coccoid infestations on Pinus taeda L. (Pinaceae), ix.1983, Toombs Co, Georgia, USA, S. Clarke, and 1 त, 3 $\uparrow, 3$ pupal exuviae, associated with Orgyia sp. (Lepidoptera: Lymantriidae), 20 km S Santo Domingo, Pichincha Prov., Ecuador, 6.viii.1980, L. Guerrero.

\section{Distribution. - Costa Rica, Panama, Ecuador, Guadeloupe, and USA (Georgia).}

Biology. - In Guadeloupe larvae live beneath remains of dead Icerya seychellarum colonies. When mature they spin silken cocoons among the scale insect debris. Pupation follows immediately and adults emerge a short time later.

This species was originally reared at several sites in Panama and Costa Rica from empty spider egg shells and egg cases. Its discovery in Guadeloupe in association with the remains of I. seychellarum colonies indicates that this species is likely to be found in other insect remains. This is confirmed by the present discovery of two previously undetermined series of C. harrisoni in the USNM: one reared in association with an unidentified coccoid infestation on Pinus taeda in Georgia, USA, the other from a lymantriid lepidopteran, Orgyia sp., in Pichincha, Ecuador.

Remarks. - The pupa of this species is the first, and the larva only the third described for a determined species of the supertribe Brachineuridi. The two others are Rhizomyia perplexa Kieffer, 1889, and Rhizomyia jaapi (Rübsaamen, 1925), both from Europe. KIEFFER (1901a: 309, 344; 1901b: pl. 25, fig. 4, 9; 1913: 107, pl. 4, fig. 6) illustrated the dorsum of the larva of $R$. perplexa for which he showed spiracles on the terminal abdominal segment, a unique occurrence in Cecidomyiidae. The ovoid, flattened larva of this species, with the head ventrally directed and obscured in dorsal view, was found feeding gregariously among the finer roots of a sedge and was reminiscent to Kieffer of a scale insect. MöHN (1955) doubted the accuracy of Kieffer's drawing because the generally similar larva of $R$. jaapi (as Coccomorpha sp. prob. jaapi) lacked spiracles on the terminal segment. MöHN (1955: 218 \& pl. 28, fig. 4-5) described also the larva of an undetermined brachyneurid, but these larvae were not associated with adults, making the determination uncertain. The larva of another species attributed to a Rhizomyia $s p$. was illustrated in MAMAEV \& KRIVOSHEINA (1965: 48, fig. 4 [1]). Its body is ovoid and flattened, resembling that of Rhizomyia jaapi except that the head is extremely large and generally similar to that of a Lestodiplosis. 


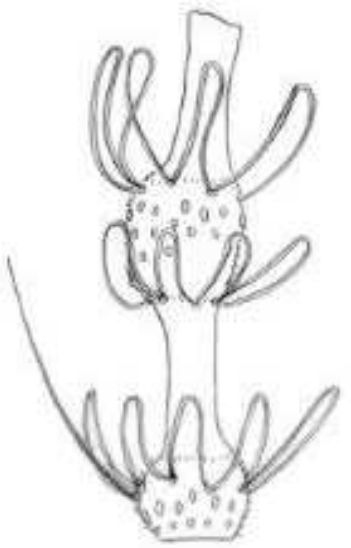

25

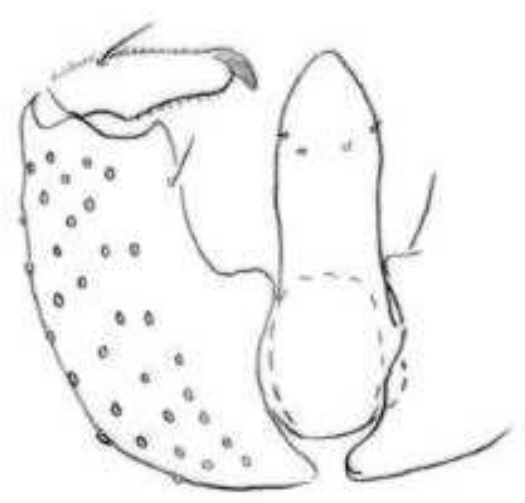

27

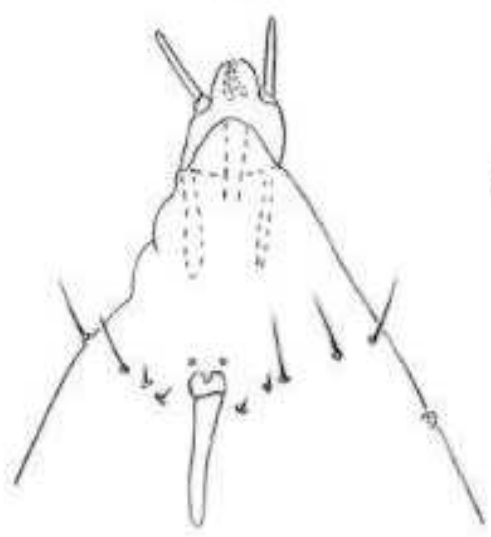

29

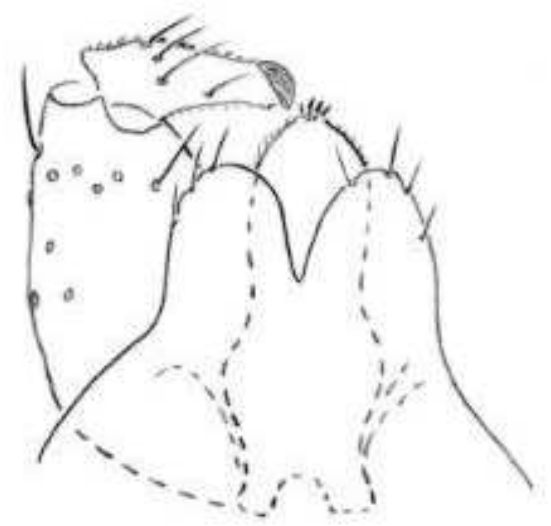

26

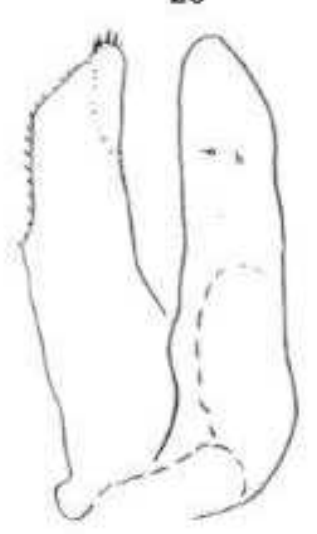

28

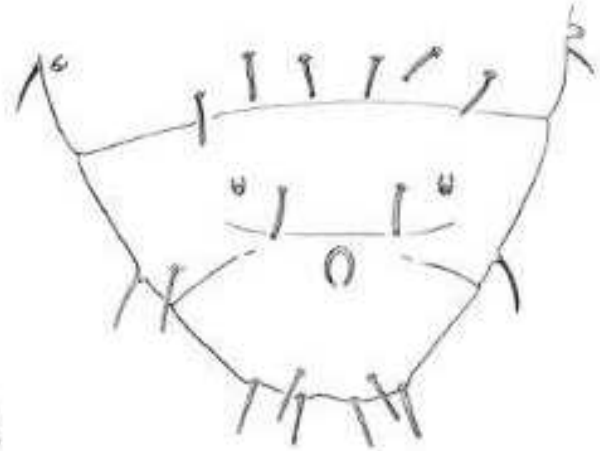

30

Fig. 25-30. - Lestodiplosis peruviana. - 25, Male third flagellomere (ventral). - 26-28, Male genitalia: 26, left gonopod, cerci and hypoproct (dorsal); 27, left gonopod and aedeagus (ventral); 28, hypoproct (on left) and aedeagus (lateral). - 29, Third instar larva, head and prothorax (ventral). - 30, Same, seventh through terminal abdominal segments (dorsal).

The larva of $C$. harrisoni shows no resemblance to that of described Rhizomyia larvae. It instead resembles predaceous cecidomyiids, e.g., Lestodiplosis spp., in its elongate-cylindrical shape, long cephalic apodemes, and conspicuously dimorphic dorsal, pleural, and terminal sets of papillae. Contrasting with the ventral anus of C. harrisoni, the anus of Lestodiplosis spp. is always situated on the dorsum of the terminal segment.

\section{Lestodiplosis peruviana Felt, 1911 (fig. 25-30)}

Adult. - Color: Male flagellomeres with basal node of each flagellomere dark, the remainder light; wing with vague dark maculations on light background; legs covered with fuscous scales.

Head: Eyes connate, 8-9 facets long at vertex; facets circular, all closely adjacent. Occiput with dorsal protuberance. Frons with 5-7 setae per side. Labella generally hemispherical, pointed apically, 
each with 6-8 lateral setae. Palpus 4-segmented. Male antennal flagellomeres (fig. 25) binodal, with one circumfilum on the basal node, two on the distal, the loops of all three circumfila subequal in length. Female flagellomeres with circumfila mostly appressed to node, but slightly bowed at apex.

Thorax: Wing 1.0-1.2 $\mathrm{mm}$ long, $\mathrm{R}_{5}$ slightly bowed, joining $\mathrm{C}$ anterior to wing apex. Acropod: claws untoothed, curved beyond midlength; empodia attaining bend in claws; pulvilli less than 1/3 length of empodia.

Male abdomen: First through sixth tergites entire, rectangular, with single row of posterior setae, no lateral setae, scales concentrated on posterior half, and anterior pair of trichoid sensilla; seventh and eighth tergites with anterior pair of trichoid sensilla the only vestiture. Genitalia (fig. 26-28): cerci with rounded posterior margins; hypoproct longer than cerci, wide, tapering towards apex, of same length and shape in dorsoventral aspect as aedeagus, setulose throughout, with short setae concentrated at apex; aedeagus cylindrical, tapering towards apex, with pair of setose papillae on each side between apex and midlength; gonocoxite short-cylindrical with rounded, setulose mediobasal lobe; gonostylus short, tapering gradually from base to toothed apex, completely setulose.

Female abdomen: First through seventh tergites as in male first through sixth; eighth tergite with anterior pair of trichoid sensilla only; cerci large, elliptical, slightly pointed apically, each with ventral field on posterior half of about 30 short, closely-set, peg-like setae.

Third instar larva (fig. 29-30). - Head robust, cylindrical, tapering anteriorly, antenna almost as long as exterior head capsule, apodemes as long as head capsule. Integument dorsally and laterally smooth, and ventrally mostly so, the anterior third of meso- and metathorax and first through seventh abdominal segments with rows of dense spicules, among which issue pseudopods characteristic of the genus, 2 each on meso- and metathorax, 3 each on first through seventh abdominal segments. Spatula present with 2 rounded anterior lobes and elongate shaft. Terminal segment with a trio of convex pads covered with spicules, the anus dorsal. Papillae as follows: sternals without setae seen on thoracic segments but not apparent on abdomen; 2 pairs of lateral papillae on each side of median line of thoracic segments, one of each pair with elongate seta, the other without seta; dorsal and pleural papillae of thoracic segments with elongate setae, tapering to apex, setae of two inner pairs of dorsal papillae on abdomen also elongate but wider and blunt to forked at apex, setae of the outer pair and pleural papilla pointed at apex on first through sixth abdominal segments, then also blunt or forked on seventh and eighth; terminal segment with 3 pairs of papillae with elongate blunt-tipped setae.

LECTOTYPE, here designated, 1 đ, Catacaos, "C.J.," Peru, 29-viii-1910, [C.H.T.] T[ownsend], from Pinnaspis strachani (Cooley) (as Hemichionaspis minor Maskel), a3528, deposited in UsNM. Paralectotypes [= Arthrocnodax meridionalis], 8 larvae, Coscomba, Peru, 24-viii-1910, a3528, deposited in USNM.

Other specimens examined. - GP 1278, ex Diaspis boisduvalii Signoret (Hemiptera: Diaspididae)

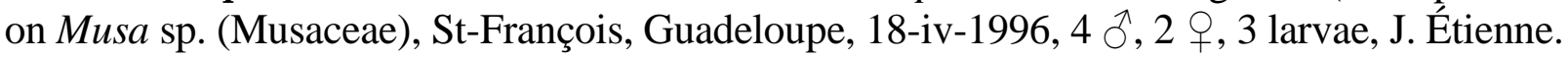

Remarks. - The original pro forma description of this species in FELT (1911) was based on uncleared, poorly slide-mounted specimens. The genitalia of the only included adult, a male, were mounted in side view and were meaningless without new material for comparison (HARRIS, 1968). We were able to resolve the identity of this species through the fortunate discovery of a series of adults and larvae from Guadeloupe, also reared from a diaspidid scale. The male genitalia of one fresh specimen mounted in side view allowed us to determine that it belonged to L. peruviana. The paralectotype larvae, however, belong not to L. peruviana but to Arthrocnodax meridionalis Felt. This identification was made possible because of a revision of Arthrocnodax in preparation by one of us (RG). It is doubtful that these larvae from Peru were feeding on a diaspidid because all Arthrocnodax species known to us are predators of eriophyid mites (Acarina).

Lestodiplosis peruviana is one of eight species of Lestodiplosis known to be associated with scale insects (Coccoidea). The seven others are: L. diaspidis (Kieffer) from a diaspidid in Italy; L. moricola (Kieffer) from a diaspidid in South Africa; $L$ dactylopii (Del Guercio) from a dactylopiid in Italy; L. aulacaspidis (Del Guercio) from a diaspidid in Italy; L. lacciferae (Barnes) from a kerriid in Malaysia; L. aonidiellae Harris from a diaspidid in South Africa; and 


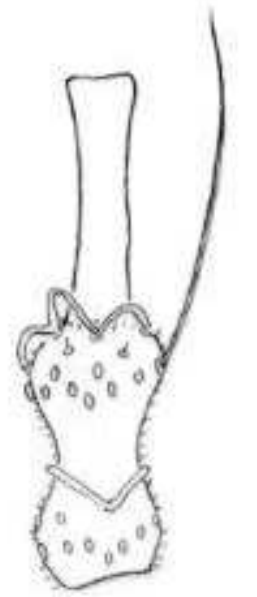

31
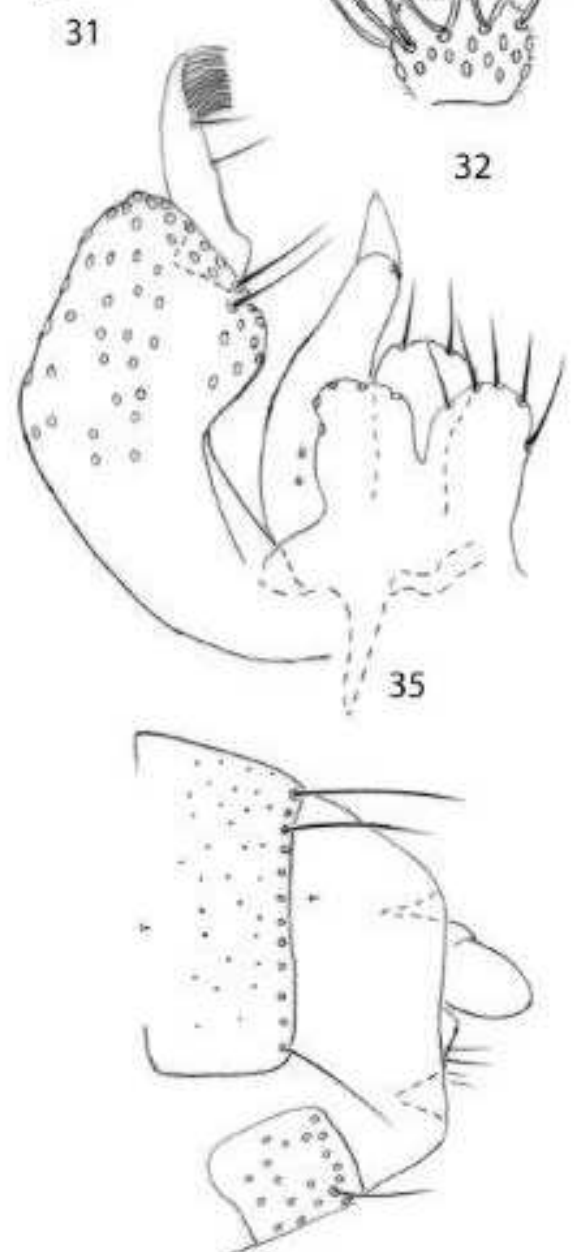

38

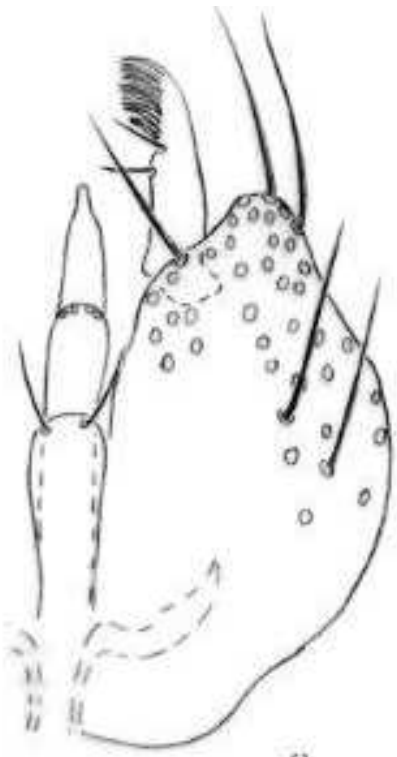

34

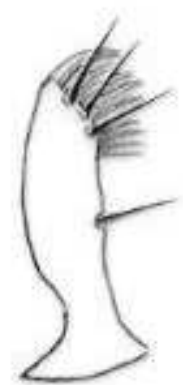

36

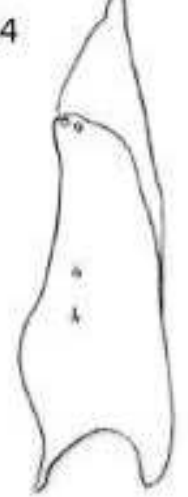

37

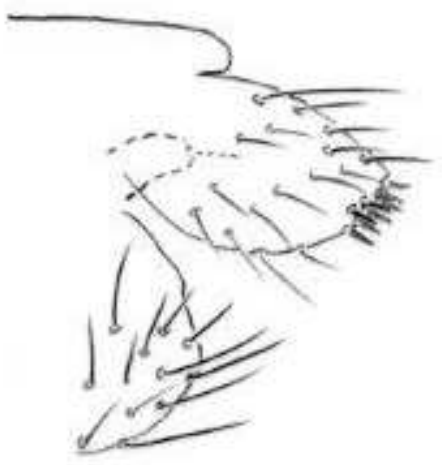

39

Fig. 31-39. - Pectinodiplosis erratica. - 31, 32, Third flagellomere (lateral), female and male. - 33, Acropod (lateral). - 34, Male genitalia, only one gonopod shown and cerci removed (dorsal). -35 , Male genitalia, only one gonopod shown (holotype, distorted on mount; dorsolateral). - 36, Gonostylus (ventral). - 37, Aedeagus (lateral). -38 , Female postabdomen (lateral). - 39, Detail of female tenth segment and cerci (lateral).

L. laticaulis Gagné from a diaspidid in Florida, USA (GAGNÉ, 2004). The first four species cannot now be identified: they were not well-characterized and their types are lost, but it should be possible in due course to find and redescribe those species again. The male genitalia were well described for only the last two species. HARRIS (1968) indicated that the male genitalia of the Barnes species were generally similar to those of L. aonidiellae but that the two species differed in characters found elsewhere on the body. Lestodiplosis peruviana and L. laticaulis have a stout aedeagus as long and as wide as the hypoproct, while L. aonidiellae and L. lacciferae have a narrow aedeagus only about half as wide but twice as long as the hypoproct. Lestodiplosis peruviana lacks the narrow, pointed mesobasal gonocoxite lobe found on $L$. laticaulis, but for more details see GAGNÉ \& BENNETT (1993). 


\section{Pectinodiplosis erratica (Felt, 1908) (fig. 31-39)}

Adult. - Color: Antennal flagellomeres white except for black base of node on female and basal node on male. Thorax white. Wing yellowish white except for horizontal dark bands of scales and hairs across 2nd fifth and distal sixth. Fore- and midlegs black on distal third of femur, basal third of tibia, and first 2 tarsomeres, white elsewhere; hindleg black on all of femur, basal two-thirds of tibia, first tarsomere and basal two-thirds of 2nd tarsomere, white elsewhere. Abdomen yellow, covered with fuscous scales through 7th segment.

Head: Eyes connate, 9-10 facets long at vertex; facets circular, all closely adjacent. Occiput with prominent dorsal protuberance bearing two long apical setae. Frons with 4-7 setae per side. Labella generally hemispherical, slightly pointed apically, each with 6-7 lateral setae. Palpus 4-segmented. Male antennal flagellomeres (fig. 32) binodal, with one circumfilum on each node, the loops of both circumfila lenghtening from venter to dorsum of node. Female flagellomeres (fig. 31) with neck approximately as long as node, circumfila mostly appressed to node, slightly bowed at apex.

Thorax: Wing length, 1.1-1.2 $\mathrm{mm}$ in male $(\mathrm{n}=5), 1.1-1.3 \mathrm{~mm}$ in female $(\mathrm{n}=5), \mathrm{R}_{5}$ bowed to join $\mathrm{C}$ posteriad of wing apex. $\mathrm{Cu}$ forked. Femora with ventral row of long setae. Acropod (fig 33): claws untoothed, curved near midlength; empodia not attaining bend in claws; pulvilli less than 1/3 length of empodia.

Male abdomen: First through sixth tergites entire, rectangular, with single row of posterior setae, 0 lateral setae, scales evenly distributed, and anterior pair of trichoid sensilla; seventh and eighth tergites with anterior pair of trichoid sensilla the only vestiture. Genitalia (fig. 34-37): cerci broadly rounded apically, with 5-6 long setae along margin; hypoproct slightly longer than cerci, apex broadly rounded, with only two posterior setae; aedeagus somewhat longer than hypoproct, as long as gonocoxite, bilaterally compressed, apical third membranous and pointed, the more rigid base with pair of setose papillae on each side near midlength and several non-setose papillae anterior to membranous portion; gonocoxite swollen laterally, setae absent on basal two-fifths, numerous and robust beyond; gonostylus elongatecylindrical, pinched at base, surface glabrous, with only a few subapical and apical setae present, apical tooth long and broad, pectinate.

Female abdomen (fig. 38-39): First through seventh tergites as in male; eighth tergite with anterior pair of trichoid sensilla the only vestiture; ninth sternum with scattered setae; tenth tergum without setae; cerci large, elliptical, with scattered setae and apicoventral field of about 10 closely-set, short setae; hypoproct with 2 apical setae.

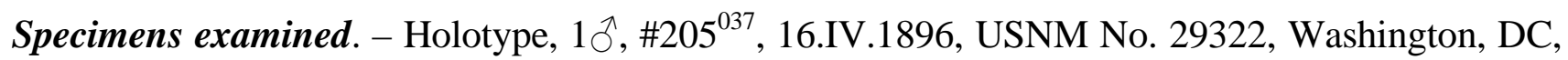
Hemerocampa leucostigma (J.E. Smith); 3 ô, 4, , GP2543, on Ceroplastes ceriferus (Fabricius) (Coccidae), Petit-Bourg, Duclos, Guadeloupe, 3.vii.2007, J. Étienne; 17 ô, 10 ㅇ, GP2606, on Parasaissetia nigra (Nietner) (Coccidae), Lamentin, Ravine-Chaude, Guadeloupe, 17.ii.2008, J. Étienne; 1 ô, GP2627, 14.iii.2008 and 1 ऊ, GP2630, 15.iv. 2008, on Crypticerya genistae (Hempel) (Monophlebidae) remains on Mimosa pigra, Jarry, Baie-Mahault, Guadeloupe, J. Étienne.

Remarks. - This species was originally described (FELT, 1908) and subsequently redescribed (FELT, 1918) on the basis of a single male without locality or biological data but with an associated number, $205^{037}$, that gave a promise of locality and/or host data. Much later (GAGNÉ, 1973) a card with the code number was found in U.S. Department of Agriculture files giving the collection locality as Washington, D.C., and the host as Hemerocampa leucostigma, a lymantriid lepidopteran.

Rearings from Guadeloupe of this species are the first record of this species since 1896 and allow us to redescribe the male and describe for the first time the female. The discovery of $P$. erratica on scale insects, a coccid and a monophlebid, indicates that the species may be a general coccoid predator. Even though this species was not observed to prey on these coccoids, we assume from the general morphology of the adults, as well as the black bolus in the adult abdomen characteristic of predaceous cecidomyiids, that this species is a predator. 
Laboratory Manager, Smithsonian Institution for his assistance with the scanning electron microscope, and Diana Marquez for electronically arranging the drawings and SEM photos onto plates. We are grateful also to: Keith M. Harris, Woking, Surrey, United Kingdom; Allen L. Norrbom and Natalia Vandenberg, Systematic Entomology Laboratory, and an anonymous reviewer for their comments on a draft of the manuscript.

\section{REFERENCES CITED}

Clarke J. M., 1913. - Fosseis Devonianos do Paraná. Monografias Servico Geologico e Minerologico do Brasil 1: 1-135.

Felt E. P., 1908. - Appendix D. P. 286-422, 489-510, pl. 33-34. In his 23d report of the State Entomologist on injurious and other insects of the State of New York 1907. New York State Museum Bulletin, 124: 5-541, 44 pl.

- 1911. - A new Lestodiplosis. Entomological News, 22: 10-11.

1918. - Appendix: A study of gall midges VI. Pp. 76-205, 213-230, pl. 4-12. In his 33rd Report of the State Entomologist on injurious and other insects of the State of New York 1917. New York State Museum Bulletin, 202: 7-240, 12 pl.

GAGNÉ R. J., 1968. - Chrybaneura harrisoni, a new genus and species from Central America (Diptera: Cecidomyiidae). Proceedings of the Entomological Society of Washington, 70: 33-35.

— 1973. - A generic synopsis of the Nearctic Cecidomyiidi (Diptera: Cecidomyiidae: Cecidomyiinae). Annals of the Entomological Society of America, 66: 857-889.

- 1989. - The Plant-Feeding Gall Midges of North America. Cornell University Press, Ithaca, New York. xiii +355 p. \& 4 pls.

— 1994. - The Gall Midges of the Neotropical Region. Cornell University Press. xv \& 352 p.

2004. - A catalog of the Cecidomyiidae (Diptera) of the world. Memoirs of the Entomological Society of Washington $\mathrm{n}^{\circ} 23,408 \mathrm{p}$.

GAGné R. J. \& BennetT F. D., 1993. - Two new species of Lestodiplosini (Diptera: Cecidomyiidae) preying on Homoptera and Thysanoptera in southern Florida. The Florida Entomologist, 76: 341-348.

Gagné R.J., Blanco-Metzler H. \& Étienne J., 2000. - A new Neotropical species of Clinodiplosis (Diptera: Cecidomyiidae), an important new pest of cultivated peppers. Proceedings of the Entomological Society of Washington, 102: 831-837.

GAGné R. J. \& ÉtIENnE J., 1996. - Meunieriella avicenniae (Cook) (Diptera: Cecidomyiidae) the leaf gall maker of black mangrove in the American tropics. Proceedings of the Entomological Society of Washington, 98: 527-532.

- 2006. - Gephyraulus mangiferae (Felt), n. comb. (Diptera: Cecidomyiidae): a mango pest from India newly recorded from the Western Hemisphere. Proceedings of the Entomological Society of Washington, 108: 930-937.

HARRIS K. M., 1968. - A systematic revision and biological review of the cecidomyiid predators (Diptera, Cecidomyiidae) on world Coccoidea. Transactions of the Royal Entomological Society of London, 119: 409-494.

HouArd C., 1933. - Les Zoocécidies des Plantes de l'Amérique du Sud et de l'Amérique Central. Hermann et Cie, Paris. 549 p.

KIEFFER J.-J., 1898. - Synopse des cécidomyies d'Europe et d'Algérie décrites jusqu'à ce jour. Bulletin de la Société d'Histoire Naturelle de Metz (2)8: 1-64.

1901a \& b. - Monographie des cécidomyides d'Europe et d'Algérie. Annales de la Société Entomologique de France, 69: 181-384, pl. 15-24 \& 69: 385-472, pl. 25-44.

1913. - Diptera. Fam. Cecidomyidae. Fasc. 152, 346 p., 15 pl. In Wytsman, P., ed., Genera Insectorum. Bruxelles.

McAlpine J. F., Peterson B.V., Shewell G. E., Teskey H. J., Vockeroth J. R. \& Wood D. M. (eds), 1981. - Manual of Nearctic Diptera. Vol. 1. Research Branch, Agriculture Canada, Monograph 27, vi + 674 pp.

Mamaev B. M. \& Krivosheina N. P., 1965. - [The Larvae of Gall Midges (Diptera, Cecidomyiidae).] Akademiya Nauk USSR, Moscow. Translated, 1993, Roskam J. C. \& Balkema A. A. ed., Rotterdam, ix +293 p. 
MöHN E., 1955. - Beiträge zur Systematik der Larven der Itonididae (Cecidomyii-dae, Diptera). 1. Teil: Porricondylinae und Itonidinae Mitteleuropas. Zoologica, 105 (1, 2): 1-247, $30 \mathrm{pl}$.

ÖZDIKMEN H., 2009. - New names for two gall midges genera (Diptera: Cecidomyiidae). Munis Entomology \& Zoology, 4: 201-203.

RÜBSAAMEN E. H., 1925. - In Rübsaamen E.H. \& Hedicke H., 1925, Die Cecidomyiden (Gallmücken) und ihre Cecidien. Allgemeiner Teil. Zoologica (29) 77: 1-112, pl. I-X [p. 42].

Russo R., 2008. - First description of the stem gall of Rhopalomyia baccharis Felt, 1908 (Diptera: Cecidomyiidae), on Baccharis pilularis De Candolle (Asteraceae). Pan-Pacific Entomologist, 83: $285-288$.

TAVARES J. S., 1917. - Cecídias brazileiras que se criam em plantas das famílias das Compositae, Rubiacea, Tiliaceae, Lythraceae e Artocarpaceae. Brotéria, Série Zoológica, 15: 113-181, pl. VI-XI. 